\title{
Etika asistentzian vs. etika gizarte eskuartzean: egoeraren analisia
}

\section{Maialen San Sebastian Kortajarena}

\author{
Bergarako Udala \\ maialenss@gmail.com
}

La presencia de la ética está cada vez más interiorizada entre los profesionales que trabajan con las personas y consecuentemente los dilemas éticos que surgen (con los usuarios, las decisiones a tomar, las líneas de acción de la organización...) son cada vez más numerosos. Esto requiere la necesidad de proporcionar respuestas y, por ello, cada vez se están creando más comisiones de ética. En el presente trabajo, partiendo de conceptos como la bioética, los comités de ética o los dilemas, se quiere analizar la importancia y el desarrollo de la ética en diferentes ámbitos y planos, para llegar a estudiar la situación de los comités de ética asistencial y los comités de ética en intervención social del País Vasco y Navarra. A tal fin, se estudia el marco teórico que rodea a este tema, para después investigar la situación actual de las comisiones de ambas áreas, comparándolas e examinando distintas variables.

\section{Palabras clave:}

Ética, comités de ética, ética asistencial, intervención social, País Vasco, Navarra.

\section{GAKO-HITZAK:}

Etika, etika batzordeak, asistentziaren etika, etika gizarte eskuartzean, Euskal Autonomia Erkidegoa, Nafarroa. 


\section{Sarrera}

XX. mendeko azken hiru hamarkadetan, maila zientifikoan eta teknologikoan ematen ari zen garapen azkarrak eta honek jendearengan sortzen zuen zalantza, ezinegon eta babesgabetasun sentimenduen aurrean, diziplina berri bat eratu zen; bioetika. Honen helburua bai osasun arloan (medikuntza, erizaintza, farmazia) eta baita biziaren zientzietako (biologia, oro har, eta genetika, bereziki) diziplinetan ematen ziren arazo etikoei erantzuna ematea edo gutxienez aztertzea zen. Gizartean eman diren aldaketen aurrean eta profesio berriak sortzearekin batera, bioetikaren hedapena gizarte eskuartzeko arloetara ere zabaldu da.

Bioetikaren garapena ezberdina izan da aurrez aipatu diren bi arloetan, hau da, osasun arloan eta gizarte eskuartzearen arloan. Kontzeptu honen inguruko lehen erreferentziak eta profesionalek egindako lehen eskuartzeak, osasun edo medikuntzaren arloan aurkitzen dira eta urte batzuk beranduago zabaltzen da gizarte eskuartzearen arlora. Aipatu den moduan, bioetikaren inguruan azterketa kronologiko bat eginez gero osasun arloa beti gizarte eskuartzea baino pauso bat aurrerago joan dela ikusten da eta bai arlo honen bilakaera bai legediaren garapena maila eta garai ezberdinetan landu dira.

Artikulu honen helburua, osasun arloan eta gizarte eskuartzearen arloan Euskal Autonomia Erkidego (EAE) eta Nafarroa mailan dauden batzordeen egoera aztertzea da, aldagai ezberdinak erlazionatu eta konparatuz. Horretarako, hurrengo pausoak eman dira:

- Gai honen inguruko marko teorikoa landu.

- EAE eta Nafarroa mailako batzorde ezberdinen inguruko diagnostikoa egin.

- Batzorde ezberdinen egoera konparatu arloka (Osasuna/Gizarte eskuartzea).

- Batzorde bakoitzaren egoera konparatu probintzi eta erkidegoaren arabera.

\section{Kontzeptuen azalpena: marko teorikoa eta testuingurua}

\subsection{Bioetika}

Bioetika kontzeptua bere jatorri etimologikoan bizitzaren etika gisa definitzen da, baina Potter-ek ${ }^{1}$ erabilitakoa da gure lan honen oinarrian interesatzen zaigun eta aurkitzen den definizioa. Bere definizioari jarraituz, bioetika biologiaren eta ezagutza humanistikoen arteko nahasketa gisa ulertzen da, eta bere helburua da aurrerapen zientifikoek biologian, osasunean eta ingurunean izan dezaketen eragina ahalbidetu eta aldi berean mugatzeko arauak eta printzipioak finkatzea (Potter, 1970).

${ }^{1}$ Jatorri holandarreko ikerkuntza onkologikoan aritutako biokimikoa zen Potter, lehen aldiz bioetikaren bidez zientziaren mundua eta balioen mundua elkartu nahi izan zituena.
Hala ere, ez zen definizio hau nagusitu arlo akademikoan, eta urte batzuetan zehar, bioetika diziplina osasun eta medikuntzaren arlora soilik murriztu zen. Gaur egun, bioetikaren kontzeptua Potter-en oinarrietara itzultzen ari da, eta horrela, bioetika era globalagoan ulertu eta aztertzen da, gaur egun sortzen diren arazo eta gatazka guztiei modu eraginkorragoan erantzun ahal izateko.

Hori horrela izanik, Bioetika honela ulertuko dugu: "medikuntzaren eta oro har biologiaren alderdi etikoak, eta era berean gizakiaren eta gainerako izaki bizien arteko harremanak aztertzen dituen diziplina" (Casado, 2016).

Lan arlo oso zabala denez eta arrazoi historiko eta kontzeptualengatik, azpiko diziplina hauek ezartzen dira:

1. Ikerketa zientifikoaren etika: ikerketan eman daitezkeen praxi txarren aurrean pertsonaren osotasun eta ongizatea defendatzeaz gain, eskuartzeko eta ikertzeko marko oso bat definitu nahi duen bioetikaren zatia.

2. Asistentziaren etika: zaintza eta asistentzia harremanetan zentratzen den bioetikaren zatia; osasuneko eta gizarte laneko profesionalen praktika profesionalean planteatzen diren auzi moralak barne hartuz.

3. Ingurumen etika: gizakiek (hurrengo belaunaldiek barne) ekosistemarekin duten harremana.

Bioetika kontzeptua lehen aldiz Fritz Jahr artzain protestanteak erabili zuen 1927an, baina ez zen sortu diziplina gisa 1970. urtera arte. Bioetikaren barruan eraldaketa hau emateko eta diziplina gisa onartzeko saltoa emateko hiru arrazoi nagusi eman ziren:

1. Aurrerapen zientifikoak eta teknologikoak eta honek gizartean izan zuen eragina.

2. Asistentzia ereduan emandako aldaketak.

3. Mediku-erabiltzaile harremanean emandako aldaketak.

Urte hauetan eman ziren gertaeren artean, hurrengoek eragin berezia izan zuten diziplinaren sorreran eta garapenean:

- 40-50 hamarkadak, hastapenak:

- Nuremberg Kodea garatzea (Alemania, 1948), mediku nazien aurka egindako epaiketetan lortutako emaitzen ondorio gisa. Gizakiekin ikerketak egitea eta etika batzen dituen lehen protokoloa izango da. Ikerketak egin ahal izateko pertsonek boluntarioki eta adostasuna emanda parte hartu behar dutela azpimarratzen du.

- "Salgo" kasua (EEUU, 1957)2.

2 Bizkarreko ebakuntza baten ostean, Martin Salgo paralitiko geratu zen, eta medikua salatu zuen ebakuntzaren ondorio edo arriskuez ongi ez informatzeagatik. Gorte Gorenak ulertu zuen medikua- 
- 60-70 hamarkaden artean bioetikaren garapena bultzatu zuten gertaera ugari eman ziren:

- 1966an onartu zen Helsinkiko Adierazpena, gizakiekin egiten ziren ikerketak jarraitu beharreko orientabideak landu zituena.

- 1967tik aurrera, bihotzeko lehen transplanteak ematean, heriotza klinikoa definitzeko arazoak sortu ziren.

- 1968an, Harvard Unibertsitateko medikuntza fakultateak argitaratutako artikulu batek, garun heriotza zehazteko irizpide berriak proposatzen zituen, eta honek, eutanasia eta "norberaren heriotzarako eskubidearen" inguruko eztabaida sortu zuen.

- 1972an, Andres Hellegersy medikuak (Georgetown Unibertsitatea, Washington), Bioetika zentro bat eratzeko lehen pausoak eman zituen. Bestalde, "Tuskegee” kasuaren ostean 3, AEBetako kongresuak "Zientzia Biomedikoen eta Portaeraren alorreko giza subjektuen Babeserako Nazio Batzordea” ezarri zuen. Gainera, Estatu Batuetan bertan, Gaixoen Eskubideen inguruko gutuna onartu zen.

- 1975ean, “Karen Ann Quinlan” kasuaren ostean ${ }^{4}$, jakinik pertsona batek ez zuela bizitza kontziente bat izango, modu begetatiboan bizirik mantentzearen eztabaida piztu zen...

- 1978an, “Zientzia Biomedikoen eta Portaeraren alorreko giza subjektuen Babeserako Nazio Batzordeak" "Belmont Txostena" 5 argitaratu zuen.

- 80. hamarkada:

- Espainiako Gobernuak 1980an, transplanteen inguruko legea onartu zuen, 426/1980 Errege dekretua.

- 1981ean, Bartzelonako Sant Joan de Déu Ospitalean, Espainiako lehen Ospitaleko Etika Batzordea eratu zen.

- 1982 eta 1983an emandako "Baby Doe 1 eta 2" kasuek, ospitaletan jaioberriak "egoki”

ren betebeharra informazio guztia ematea zela, eta ordutik, adostasun informatuaren kontzeptua erabiltzen da pertsona edo gaixoaren eskubideez hitz egitean.

3 "Tuskegee kasua", ordu arte ikerketa sekretua izan zen. Ikerketa hau oinarritu zen sifilisa zuten 400 pertsona beltz gaitzaren aurkako tratamendu gabe uztean (ordurako tratamendu eraginkorrak egon arren), gaixotasunaren garapen "naturala" aztertu asmoz.

${ }^{4}$ Karen Ann Quinlan atzera bueltarik ez zuen koman sartu zen, eta modu begetatiboan mantendu zuten bizirik horren ondoren. Bere gurasoek arnas hartzeko aparatua itzaltzeko eskatu zuten bakean hiltzeko. Epaitegi baten ezezkoaren aurrean, New Jerseyko Auzitegi Gorenera jo zuten, eta honek, makina deskonektatzeko baimena eman zieten, "heriotza duin eta baketsurako eskubidean" oinarrituz.

${ }^{5}$ Belmont txostenak Biomedikuntzako ikerketetan partehartzen duten pertsonen eskubideak babesteko gidalerroak ezartzen ditu, autonomia, benefizentzia eta justizia printzipioetan oinarrituta.

${ }^{6}$ AEBetan Down sindromea eta estenosis pilorika zituen haur baten kasuan, gurasoak ebakuntza egitera ukatu ziren (nahiz eta \%9oeko probabilitatea izan ebakuntza honekin bizirik jarraitzeko), baina 5 . egunean zendu egin zen haurra. 1983. urtean, espina bifidus eta mielomenigozele gaixotasunekin jaiotako ume baten kasuan, gurasoek erabaki zuten ebakuntza berehala ez egitea, eta abokatu batek salatu egin zituen ebakuntza beharrarazteko. Epaileek gurasoen alde egin zuten, eta ebakuntza beranduago egin ostean, 6 hilabetetara tratatzeko gidalerroak lantzea ekarri zuen. 1984ean, Estatu Batuetako Gorte Gorenak baliogabetu egin zuen, baina eztabaidak indarrean jarraitu zuen. Aldi berean, Ospitaleek Neonatologian Etika Batzordeak izatea bultzatu zuen.

- 1984ean, xenotrasplanteak hasi ziren.

- 1985ean, Espainiako Auzitegi Konstituzionalak 53/1985 sententziaren bidez, kasu batzuetan abortatu ahal izateko eskubidea arautu zuen.

- 1986an, "Baby M. kasuaren"7 ostean, ordezko amatasunaren inguruko eztabaida sortu zen eta polemika handia ekarri zuen.

- 90. hamarkada:

- 1991an, Herbehereetan eutanasia boluntarioaren inguruan argitaratutako bi ikerketek (Remmelink txostena eta Van Der Wal txostena) ${ }^{8}$, eztabaida izugarria zabaldu zuten Europa eta Estatu Batuetan.

- 1993an, giza enbrioien lehen klonazioa egin zen Estatu Batuetan eta 1997an Dolly ardia jaio zen.

- 2000. hamarkada:

- 2004ean, "Bioetikaren inguruko Arau Unibertsalen Adierazpena” zirriborroa onartu zen.

- Azken hamarkadetan, osasun arretak hiru aldaketa esanguratsu jasan ditu:

- Biztanleriaren osasuna hobetzeko aurrerapen zientifiko eta aukera ezberdinak eman dira.

- Gaixoaren eskubide legal eta etikoen onarpenak, pertsonak bere eskuartzean erabakitzeko eta kontuan hartzeko gaitasun gehiago izatea ematen dio.

- Osasun sistema berriak txertatzeak, aukera eta aurrerapen ugari ekarri ditu, baina aldi berean, gatazka eta erronka berriak sortu ditu.

Testuinguru honetan eta gertaera hauen guztien aurrean, 1979an, Beauchamp eta Childress-ek, Principles of Biomedical Ethics manuala argitaratu zuten bioetikaren lau printzipio nagusiak ezarriz. Honen helburua, gatazka etikoen aurrean profesionalari hausnarketan lagunduko dion metodo sistemiko bat eratzea zen.

Hasieran, hausnarketa garatu eta erabakiak hartu ahal izateko, lau printzipioak aplikatu behar zirela pentsatzen zuten, beti ere, euren artean talkarik gertatu ezean, eta kasu horretan, lehentasuna zeinek zuen erabaki behar zen. $2003 a n$, Beauchamp-ek

\section{haurrari alta eman zioten}

7 Ameriketako Estatu Batuetan intseminazio artifizial bitartez sortutako lehen haurra jaio zen. Ama biologikoak, "amatasun subrogatuko kontratu" bat sinatu zuen, eta ondoren, haurraren inguruko "eskubideak" erreklamatu zizkien filiazio eta zaintzaren inguruan adopzioan haurra hartutako gurasoei. 1988an, New Jerseyko Gorte Gorenak adopzioko gurasoei eman zien zainketa eta filiazioa, baina ama biologikoak bisitarako eskubidea lortu zuen.

${ }^{8}$ Herbehereetako Gobernuak eskatutako ikerketak dira eutanasiaren praktika errealaren datu eta nondik norakoak ezagutzeko. 
buelta bat eman zion pentsaera honi eta printzipioak aplikatzerako orduan, kasu zehatzaren arabera eztabaidatuak izan behar zutela ezarri zuen.

Hauek dira printzipio nagusiak:

1. Autonomia printzipioa: pertsonaren gaitasun edota eskubidea bere kabuz aukeratzeko norbere jokabidearen arauak eta ekintzen norabidea, kanpoko eraginik jaso gabe.

2. Kalterik ez egitearen printzipioa: besteak nahita mintzeko edo kaltetzeko ekintzarik ez egiteko betebeharra. Berekin dakar ekintza batetik erator daitezkeen arazo edo gaitzak aurreikusteko gaitasunaren garapena.

3. Ongizatearen printzipioa: bestearen mesederako jokatzeko betebeharra, haren interes legitimoak errespetatuta eta sustatuta eta edozein min edo kalte ekidinda.

4. Justiziaren printzipioa: diskriminazio mota oro ekiditeko eta pertsona bakoitza dagokion bezala tratatzeko betebeharra, desberdintasun (ideologiko, sozial, kultural, ekonomiko etab.) egoerak murriztuz.

Gracia-ren (2011) arabera, aurrez aipatu diren 4 printzipioak, maximo (eremu pribatua) eta minimo batzuen barruan antolatzen dira:

- Maximoak: autonomia eta ongizatearen printzipioak esparru pribatuan kokatzen dira, pertsonek euren bizi proiektua eratzeko jarraitzen dituzten sinesmen eta balio sistemari egiten baitiote erreferentzia eta eremu honetan inork ezin dezake eta ez dagokio eragitea. Pertsona batek lortu nahi dituen maximoei dagokie, bere jokaera, erabaki eta pentsaerei zentzua ematen dietena.

- Minimoak: kalterik ez egitearen eta justiziaren printzipioek biziraupena bermatzen duten elementuei dagokie, eta erabaki pertsonalak hartu ahal izateko oinarria osatzen dute. Kalterik ez egitearen printzipioak banakakoaren bizitza ziurtatzen du, eta justiziarenak berriz, bizi pertsonala aurrera eramateko behar diren baliabide eta zerbitzuetan tratu berdintasuna bermatzen du.

\subsection{Etika asistentziala}

Etika asistentziala bioetikaren zati edo atal bat da eta honela definitu daiteke: osasun arloan kokatzen den bioetikaren atala da eta profesional eta erabiltzaileen artean sortzen diren gatazka eta arazoen aurrean hausnarketa eta erantzun morala emateko balio du (Casado, 2008).

Bioetika asistentzialaren hasierak, ikuspegi guztiz klinikoa zuen, eta ez zituen kontuan hartzen gaixotasunak dituen ezaugarri psikosozialak eta gaixotzearen prozesua. Honek, profesional eta gaixoen artean sortzen zen harremanean eta profesionalen jardunean hutsuneak egotea ekartzen zuen, eta ondorioz, hainbat profesionalen artean ikuspegi hau aldatzeko beharra sortu zen. Hori dela-eta, 70. hamarkada inguruan arreta eskaintzeko modua aldatu egin behar zela planteatu zuten, eta lan egiteko modu berri bat proposatu zuten. Ikuspegi edo jarduteko modu berri hau "medikuntza biopsikosozial" gisa izendatu zen eta honela definitu daiteke: eredu biopsikosozial honetan, pertsona gaixoa bere osotasunean artatzen da, hau da, bere patologiaz gain, kontuan hartzen dira bere sentimendu, balio eta ingurunea (Engel, 1977).

Ikuspegi berritzaile honek izugarrizko aurrerapena suposatu zuen profesional eta gaixoaren artean sortzen zen harremana ulertzeko moduan, eta erabiltzailea "gizatiarrago" bilakatzen zuen, baina ez zuen izan espero zen onarpen maila. Hala ere, gerora indarrean dagoen ereduaren aurrekari modutzat ulertu daiteke.

Gaur egun jarraitzen den eredua, "Gaixoan oinarritutako medikuntza" gisa ezagutzen da: "gaixoan oinarritutako medikuntza: gaixo bakoitzari ahalik eta osasun arreta egokiena eskaintzean datza, bere helburu, balio, lehentasun eta baliabide ekonomikoak kontuan hartuz" (Sacristán, 2013: 461).

Ikuspegi honek bioetikaren oinarriak kontuan hartzea ekarri eta errazten du.

\subsection{Etika Asistentzialeko Batzordeak}

Etika Asistentzialeko Batzordeak, kontsultako diziplinarteko batzordeak dira, osasun zentro edo erakunde bateko profesional eta erabiltzaileen zerbitzuan dihardutenak, asistentzia jardueraren ondorioz sortzen diren gatazkak aztertzeko eta ebazten laguntzeko asmoarekin. Beraz, batzorde hauek hartu beharreko erabakien eta balio etikoen artean sortu daitezkeen gatazketan erantzun bat eman ahal izateko asmoarekin sortzen dira. Honetarako, egoeraren azterketan eta iritzi trukaketan oinarritzen da, beti ere sortu den arazo etikoari ahalik eta erantzun egokiena eman ahal izateko.

Batzorde hauen ibilbidea ez da oso luzea. Euren aitzindariak, Ikerketa Klinikoko Batzorde Etikoak izan ziren eta hauen bideari jarraituz osatu ziren lehen batzordeak.

Ikuspegi orokor batetik ulertuz, gisa honetako lehen batzordea pasa den mendearen 20.hamarkadan eratu zela esan daiteke, gaixotasun mental bat izan eta haurrak izanez gero, ezindura bat izateko aukera zegoen kasuetan antzutu edo ez erabakitzeko. Hala ere, batzorde hauek mende erdialdera eratu ziren Estatu Batuetan, eta lehen batzordea Seattlen jaio zen 1960an. "Heriotzaren Batzorde"9 gisa ezagutu zen.

\footnotetext{
9 “Heriotzaren batzordeak", hemodialisi teknika berriaren onura-
} dunak aukeratzeko helburuarekin eratu ziren, baliabideak urriak bai- 
Ildo honetan, 1971ean, ospitaleek batzorde etikoen inguruan jarraitu beharreko orientabide edo ildo orokorrak onartu ziren, baina, pauso nagusia 1975 an eman zen, ondorengo bi arrazoi nagusi hauengatik:

1. Tokion, Munduko Medikuen Elkarteak eginiko 1966ko Helsinkiko Adierazpenaren berrikuspena. Asanblada honetatik ateratako berrikuntza nagusienen artean, ikerketa protokolo bakoitza aurrez batzorde etiko batek aztertua eta onartua izan behar zuela zen, eta ondorioz, Biomedikuntza Ikerketako Batzordeak martxan jartzen hasi ziren.

2. Karen Tell mediku iparramerikarrak idatziriko artikulu bat. Pediatrek askotan euren gaixoen bizitza eta heriotzaren inguruko erabakiez hitz egiten du artikuluan, eta erabaki hauek hartzen laguntzeko batzordeak eratzea proposatzen du.

Bi gertaera hauek eta “Ann Quinlan” kasuak ${ }^{10}$ izan zuten eraginaren ostean, batzordeen eraketa ofiziala, 1976an eman zen.

Apurka-apurka, Etika Asistentzialeko Batzorde hauek Estatu Batuetako ospitale ezberdinetan txertatzen hasi ziren, eta 1992tik aurrera, derrigorrezko betebeharra bihurtu zen ospitale guztiek arazo etikoak ebazteko mekanismoak ezartzea eta garatzea. Horrela, pixkanaka ospitale guztietan Etika Asistentzialeko Batzordeak garatzen joan ziren.

Espainian, lehen batzordea 1974an eratu zen Bartzelonako San Juan de Dios Ospitaleko Obstetrizia eta Ginekologia departamentuan, bertan sortzen ziren gatazka etikoak ebazte asmoz. Une horretatik aurrera, Asistentzia Batzordeak zabaltzen joan ziren ospitale ezberdinetara, hala nola, Valladolideko Rio Hortega Ospitale Unibertsitario, Nafarroako Unibertsitate Kliniko edota Madrileko La Concepcion Ospitalera, baina 1990. urtera arte mota honetako lau batzorde bakarrik zeuden estatu mailan. 1992an, Osasun eta Kontsumo Ministerioak, Etikako Batzorde Nazionalen lehen mintegia antolatu zuen, eta honek benetako bultzada eman zion Etika Asistentzialeko Batzordeen garapenari. Hala ere, lehen araudia edo lege ezarpena 1995ean eman zen, INSALUD erakundeak bioetika eta batzordeen inguruko zirkularra argitaratu zuenean ${ }^{11}$.

Autonomia erkidegoei dagokionez, Espainia mailan dauden 17 autonomia erkidego eta 2 hiri autonomoetatik, gaur egun soilik 8 autonomia erkidegok arautu eta garatu dituzte Etika Asistentzialeko Batzordeak. Hauen artean aurkitzen

tziren eta gutxi batzuentzako aukera baitzegoen. Lehen aldiz, gaixoak aukeratzeko orduan mediku irizpideez gain, bestelako irizpide batzuk erabiltzen hasi zen erabiltzaileen artean lehentasunak ezartzerako orduan.

${ }^{10}$ Duintasunez eta bakean hiltzeko arnasteko makina itzaltzeko Ann Quinlanen gurasoek eginiko eskaerak, New Jerseyko Gorte Gorenak emandako argudioen bitartez Asistentzia Batzordeen sorrera markatu zuen ofizialki.

${ }^{11}$ 3/95 Zirkularra, apirilaren zoekoa, Asistentzia Batzordeen sorrera eta egiaztapenekoa. dira Katalunia, EAE, Galizia, Nafarroa, Gaztela eta Leon (2008), Andaluzia, Madril eta Valentziako Erkidegoa, Katalunia izanik lehen autonomia erkidegoa (1993an) eta Madril azkena.

\subsection{Etika gizarte eskuartzean}

Etika presente egon da Gizarte Lanaren eta gizarte eskuartzeen garapen eta prozesuan, baina ez beti intentsitate edo maila berdinean. Gai honen inguruan Idareta, Uriz eta Viscarret-ek eginiko azterlana oinarri gisa harturik (2017) eta Salcedok (2000) eginikoa bateratuz, etapa ezberdin hauek bereiz daitezke:

\section{- 1861-1936, estoizismo aldia:}

- Testuingurua: estoizismoa eta kristautasuna nagusitzen ziren gizartean. Estoizismoa munduarekin armonian bizitzean oinarritzen da, norberaren beharrak naturarenetara egokitu eta zoriontasuna bide honetan topatuz.

- Gertaerak: aldi honetako bi erreferente nagusiak Juan Luis Vives eta San Vicente de Paul izango dira gizarte langintzaren baitan. Lehenak, eskuartzeen banakakotasuna, pertsonaren sustapen eta honen onarpena bultzatzen zituen, pobreen prebentzioa eta arreta estatuaren ardura zirela aldarrikatuz. Urte batzuk beranduago, San Vicente de Paulek Vives-en, kristautasun eta estoizismoaren erreferentziei jarraituz, arazoen aurrean pertsonak zuzen eta orekadun mantendu behar zuela aldarrikatu zuen. 1894 aldera, Estatuak arreta eta benefizentziaren inguruan zuen betebeharra onartzen hasi zen, baina ez zuenez beregain hartzen horren ardurarik, batez ere erakunde pribatuak egin ziren kargu. Horrela, 1932an lehen eskola sortu zen garai hartako benefizentzia eta asistentziak zuen kutsu erlijiosoa mantenduz. Hala ere, kontuan hartu behar da eskolaren sorrera kristautasunaren inguruan kokatu arren, antolamendu politikoa errepublikanoa zela, eta ondorioz, asistentzialismoa eta benefizentzia ez zeudela ongi ikusiak euren kutsu katolikoa zela-eta.

- Balio etikoak: bokazioa, borondate ona, hurkoari lagundu, buruaskitasuna, solidaritatea, etab.

\section{- 1936-1960, moralaren aldia:}

- Testuingurua: estatu diktatorial batean aurkitzen gara, non ezaugarri nagusiak kristautasuna eta nazioarteko isolamendu diren. Honek, gizarte langintzaren atzerakada ekartzen du nazioarte mailako erreferentziak galtzen baitira, eta berriz ere benefizentzia eta karitatera itzultzen baita.

- Gertaerak: onarpen (gizarte langileak erabiltzailea den bezala onartu eta tratatzen du) eta fiskalizazioaren aurkako printzipioak (gizarte langileak ez du erabiltzailea arazo 
edo beharren kausa bezala erruduntzat jotzen) indartzen dira profesioa defenditzeko aurreko forma edo ereduen aurrean. Ikerketa desberdinek eta profesionalek egiaztatutako printzipio hauek praktikara eraman nahi izan arren, erabat ezinezkoa zela ikusi zen, eskuartze egoki bat egiteko beharrezkoa baita ebaluatzea. 1950. urtetik aurrera, estatua pixkanaka Europa mailara zabaltzen hasten da eta nazioarteko harremanak ugaritzen hasten dira, gizarte langintzako eskolen zabalkunde eta garapena bultzatuz.

- Balio etikoak: karitatea, paternalismoa, pazientzia, borondatea, adeitasuna, etab.

\section{- 1960-1980, balioen garaia:}

- Testuingurua: aldi honen hasieran, baliabideen eskasia eta gizarte zerbitzuen koordinazio eza dira ezaugarri nagusiak, baina profesio mailan eta gizartean ematen ari den nazioarteko irekierak, pixkanaka aurreko aldietako balio eta itxitasunetik ateratzea ekartzen du, pixkanaka iritzi eta ideia kritikoagoak agertuz.

- Gertaerak: Biestek-ek (1957)12 planteatutako printzipioak aldi horretara egokitzen ote ziren edo ez eztabaida sortu zen. Autore batzuk, hala nola Butrym (1976), gizarte langintzaren hiru eskuartze motek (banakakoa, taldekakoa eta komunitarioa) Biestek-ek ezarritako printzipioetatik onuraren bat lortu zezaketela uste zuten. Beste autore batzuk aldiz, printzipio horiek banakako gizarte langintzaren barruan bakarrik kokatzen zituzten. Arlo akademikoan, profesional eta erabiltzailearen arteko harremana birplanteatzen hasi ziren eta autodeterminazio printzipioa Biestek-ek planteatzen zuen moduan zalantzan jartzen. Biestek-ek ezarritako printzipioak onartzen jarraitzen ziren, baina pertsona errespetatzearen printzipioaren zehaztapen gisa. 1968an egin zen I Kongresu Nazionalean, profesionalak etikaren beharra aldarrikatzen hasi ziren, 1976an Nazioarteko Lehen Kode Deontologikoa onartuz. Latinoamerikako mugimenduak Espainia mailara ere iristen dira, eta benefizentzia eta karitate testuinguru batetik, mugimendu kritikoagoetara pasatzen da profesioa gizarte egituren eraldaketak eta komunitate mailako mugimenduak bultzatuz.

- Balio etikoak: hasiera batean zuhurtasun, karitate, solidaritate edota justizia nagusitzen diren arren, pixkanaka eraldatu egiten dira aldi honen amaieran profesionaltasun, altruismo, erabiltzailearen onarpena, ardura eta antzekoak nagusituz.
- Testuingurua: Elizaren eragina gutxitzen ari da gizartean eta baita gizarte langintzan. Kontzientzia etikoa handituz doa profesioan.

- Gertaerak: Biestek-en printzipioetan zegoen pentsaera aldatuz doa, eta pixkanaka indarra galtzen dute. Hamarkada hauetan profesioaren eztabaida eskuartzea modu egokienean nola burutu aztertzean datza. Horrez gain, lanbidearen teknifikazio eta burokratizazioa ematen da, laguntza funtzioaren gainetik kudeaketa funtzioa gailenduz. Gertaera garrantzitsuenen artean, 1999an Espainia mailako Kode Deontologikoa eratzea aurkitzen da.

- Balio etikoak: aukera berdintasuna, solidaritatea, unibertsaltasuna, kalitatea, gertutasuna, kooperazioa, etab.

- 2002-2016, gatazka etikoak ebaztea:

- Testuingurua: etikak geroz eta garrantzi gehiago du profesionalen artean eta gatazka etikoen inguruan hitz egin eta hausnartzen da. Etikaren 3 dimentsioetan sakontzen da, eta aztertzen da gizarte langintzan hori nola txertatzen den eta zein eragin duen.

- Gertaerak: 2002an, Bermejo-k "Etica de las profesiones" argitaratzen du erabakiak hartzeko eredu bat gizarte langintzara aplikatuta planteatuz (gazteleraz egiten den lehenengo aldia), eta gai honen inguruan sakontzen jarraitzeko bide bat irekitzen du. 2006 eta 2007 an, Uriz eta bere taldeak, La auditoria ética en Trabajo Social eta Dilemas éticos en la intervencion social argitaratzen dute, profesional, profesio eta etikaren arteko harreman eta gaietan sakonduz. 2012an, Espainiako Kode Deontologikoaren berrikuspen bat egiten da, aurrekoa errealitate berrira egokitzeko asmoz.

- Balio etikoak: unibertsaltasuna, kooperazioa, solidaritatea, malgutasuna, kalitatea, lehiakortasuna, espezializazioa, eskubidea...

Gaur egun, Gizarte Eskuartzearen Etika iturri ezberdinetan oinarritzen da (kode deontologiko, Giza Eskubideen Aldarrikapen Unibertsala, Nazio Batuen araberako Gizarte Zerbitzuetako printzipioak, Gizarte Zerbitzuen inguruko legedi eta arauak...) eta funtsean hurrengo printzipioak jarraitzen ditu: autodeterminazioa, justizia, duintasuna, askatasuna eta autonomia, ongintza, berdintasuna, justizia soziala, partehartze eta osotasuna.

\subsection{Gizarte eskuartzeko Etika Batzordeak}

Gizarte eskuartzeko Etika Batzordeen ibilbidea oso laburra da, eta oraindik bere hasieratan kokatzen dela esan daiteke. Hori horrela izateko, ondorengo hauek dira arrazoi nagusiak (Goikoetxea, 2013):

- Alde batetik, Gizarte Zerbitzuetarako eskubideen aitortza eta berauen ibilbidea oso berriak dira, eta ondorioz, eskuartzeen profesionalizatze, lanbide 
propioaren bai sistematizazio eta hedapena oso berriak dira.

- Bestetik, orain dela gutxi arte indarrean egon den harreman eredu paternalista izan da, non kasuaren ardura morala ia-ia profesionalaren esku zegoen bakarrik, eta erabiltzaile-profesional arteko harremana ez zen simetrikoa, eta profesionalaren erabaki eta iritziak gailentzen ziren. Ondorioz, gatazka edo arazo etikoak sortzeko aukerak ere urriagoak ziren.

Gaur egun, ikuspegi hori aldatu egin da, eta gizarte zerbitzuen helburu nagusiak ondorengo hiru maila hauetan kokatzen dira: 1) erabiltzailea gaitzea, 2) gizarteratzea eta 3) babestea. Erabiltzailearen papera edo rola ere aldatu egin da, eta aurrez aipatu diren helburuak lortu ahal izateko, hartu beharreko erabakietan eta eman beharreko pausoetan erabiltzaileak oso presente egon behar du. Honek, prozesuan zehar sortzen den harremana simetrikoa izatea ekartzen du, erabiltzailea eskuartzearen parte egitea, bere iritzi edota balioak kontuan hartzea, baina aldi berean, ugaritu egiten du gatazka edo arazo etikoak sortzeko aukera. Hau horrela izanik, arazo berri hauei erantzun ahal izateko instrumentu eta prozedura berriak sortu behar dira eta testuinguru horretan sortu eta garatzen dira Batzorde Etikoak. Inguruabar honetan, ekarpen garrantzitsuak egin ditzakete Batzorde Etikoek, Marije Goikoetxeak (2013) aipatzen duen moduan:

- Gizarte Zerbitzuetan hartzen diren erabakietan zuhurtziaz jokatzeko eta hausnarketa bultzatzeko tresna baliagarriak izan daitezke.

- Profesionaltasun eta profesioa garatzeko tresna izan daitezke.

- Gizarte Zerbitzuak eraikitzeko eta printzipio eta irizpideak garatzeko baliagarriak izan daitezke.

- Gizarte eskuartzeko ereduaren sistematizazioa bultzatu dezakete.

- Sistema formal eta informalen koordinazioa bultzatu eta erraztu dezakete.

- Eskubideen garapena eta eskuartzeen kalitatea hobetu dezakete.

- Kolektibo ezberdinen berdintasunean aurrerapausoak ematen lagundu dezakete.

Gizarte Eskuartzeko Etika Batzordeen inguruko lehen erreferentziak aztertzen badira, hauek 1987an aurkitzen dira, eta euren erabilgarritasuna azpimarratzen da nagusiki. Garai horretan Batzorde horiek garatu zitzaketen funtzioen artean, ondorengo hauek aurkitzen ziren (Reamer, 1987: 188-192):

1. Prestakuntza.

2. Politika publikoak garatzea.

3. Kasu konkretuen kontsulta organoa.

4. Kasuen azterketa.

Gaur egun funtzio horiek indarrean jarraitzen dute, eta, gainera, hurrengo hauek gehitu zaizkie:
- Gizarte Zerbitzuen eskuartzean eman daitezkeen arazo edo dilema etikoak aztertzea eta berauen ebazpenean aholkularitza eskaintzea.

- Balioen arteko gatazken ondorioz sortzen diren arazoetan jardute protokoloak garatu ahal izateko orientazioa eskaintzea.

- Gizarte Zerbitzuetako profesionalen artean prestakuntza sustatzea, erabakiak hartzeko orduan balio eta eskubideen ikuspegia barneratu ahal izateko eta bioetikaren printzipioak jarraituz jardun ahal izateko.

\section{Ikerketaren metodologia}

Ikerketa hau aurrera eraman ahal izateko, errealitatearen analisi bat burutu da. Rubio eta Varas-ek (2004) adierazten duten moduan, errealitatean inguruko analisi orok, ikuspegi kuantitatibo bat izango duen ikerketa du oinarri.

Ikerketa kuantitatiboa, aurretik zehaztutako adierazle batzuk modu kuantitatibo edo zenbakizkoan jaso, prozesatu eta aztertzean datza. Definizio ezberdinak aurkitu ditzakegu, baina Hernandez et al.-ek honela ulertzen du: "ikerketa galderak erantzuteko eta aurkeztutako hipotesiak frogatzeko datuen bilketa eta azterketa erabiltzen du eta zenbakizko neurketa, zenbaketa eta estatistika erabili ohi ditu aztertutako laginaren jarrera patroiak zehazteko" (Hernandez, 2003: 5).

Ikerketa kuantitatiboaren bidez, gaiaren inguruko informazioa bilduko da eta honek, bigarren mailako ikerketa burutzea ahalbidetuko du. Ikerketa mota hau beste ikertzaile batzuek bildutako datuen azterketan datza, eta horretarako, ikerketa ezberdinen berrikuspena, meta-analisia (adierazleen bidez beste ikertzaileek egindako azterketetatik lortutako datuak aztertu, sintetizatu eta laburtzea ahalbidetzen du) eta bigarren mailako azterketa egin daiteke. Kasu honetan, azterketa ezberdinen berrikuspena eta bigarren mailako azterketa erabili dira, lehenengoak errealitatearen inguruan dagoen jakintzaren sintesi bat egitea ahalbidetzen baitu, eta bigarrenak, azterketa konparatibo bat egitea.

\section{Ikerketaren emaitzak}

Ikerketa burutu ostean lortutako emaitzak hurrengoak dira.

\subsection{Etika Asistentzialeko Batzordeak vs. Gizarte eskuartzeko Etika Batzordeak}

1. taulan biltzen dira Etika Batzordeen artean nabarmentzen diren ezaugarriak. 


\begin{tabular}{|c|c|c|}
\hline & Etika asistentzialeko batzordeak & Gizarte eskuartzeko etika batzordeak \\
\hline Definizioa & $\begin{array}{l}\text { Batzorde aholkulari eta diziplinartekoa izango } \\
\text { da, osasun erakundeetako eta bertako langile eta } \\
\text { erabiltzaileen zerbitzura egongo direnak, sor daitezkeen } \\
\text { arazo etikoak aztertu, aholkatu, orientatu eta } \\
\text { konpontzera bideratuta. }\end{array}$ & $\begin{array}{l}\text { Diziplinarteko kontsulta batzorde independentea, gizarte } \\
\text { zerbitzuen alorrean gerta } \\
\text { daitezkeen gatazka etikoak ebazteko aholkularitza eskaini } \\
\text { eta erabiltzaileekin ematen diren harremanetan suerta } \\
\text { daitezkeen zalantzazko egoeretan } \\
\text { erabakiak hartzea ahalbidetzeko sortua dena. }\end{array}$ \\
\hline Funtzioak & $\begin{array}{l}\text { - Interes taldeen artean (profesionalak, gaixoak, familia } \\
\text { eta erakundea) gatazka etikoak sortzen dituzten } \\
\text { gai klinikoetan erabakiak hartzeko azterketa egin, } \\
\text { aholkularitza eskaini eta erabakitze prozesuan } \\
\text { lagundu. Batzorde hauek emandako erabakiak ez dira } \\
\text { lotesleak. } \\
\text { - Bioetika gaietako prestakuntza (eztabaidak, } \\
\text { mintegiak, bilerak, ikastaroak...) eskaintzen parte } \\
\text { hartu, batez ere batzordeko kideak formatzen. } \\
\text { Gatazka sortzen duten gaiei erantzun ahal izateko } \\
\text { gida eta protokoloak prestatu eta profesionalek } \\
\text { egunerokotasunean izan behar duten jarreraren } \\
\text { inguruko gidak eratu. }\end{array}$ & $\begin{array}{l}\text { - Eskuartzaileen arteko (profesionalak, erabiltzaileak } \\
\text { eta beren senideak, zentroak, zerbitzuak, erakundeak } \\
\text { edo administrazioak) gatazka etikoko egoeretan, } \\
\text { erabakiak hartzeko prozesua aztertu, aholkatu eta } \\
\text { erraztea. Horretarako, txosten eta gomendioak egingo } \\
\text { dira, aholkularitza eskatzen duten kasu zehatzetan. } \\
\text { Batzordeak hartzen dituen erabakiak lotesleak dira. } \\
\text { - Gatazka etikoko egoeretarako (zehatz nahiz orokorrak) } \\
\text { jarduera protokoloak edo gomendio agiriak egin eta } \\
\text { proposatzea. } \\
\text { - Gizarte zerbitzuekin lotutako profesional edo } \\
\text { boluntarioen eta batez ere Batzordeko kide direnen } \\
\text { prestakuntzan lagundu eta sustatu, etikari buruzko } \\
\text { gaietan. } \\
\text { Beren jarduera gainerako Etika Batzordeekin } \\
\text { koordinatzea eta sortu daitezkeen Batzorde berrien } \\
\text { eraketan laguntzea. } \\
\text { - Funtzionamenduari buruzko araudia egin eta onartu. } \\
\text { Batzordearen jarduerei buruzko urteko memoria egin. }\end{array}$ \\
\hline $\begin{array}{l}\text { Ez dira funtzio } \\
\text { propioak }\end{array}$ & $\begin{array}{l}\text { - Profesionalen praktika edo jarduna epaitu. } \\
\text { - Zentroaren aurka aurkezten diren kexa eta salaketen } \\
\text { aurrean, iritzia eman edo txostenak egin. } \\
\text { - Profesionalen, sindikatuen edo zentroaren inguruko } \\
\text { antolaketa eta kudeaketaren inguruan eman } \\
\text { daitezkeen kexen inguruan aholkatu. } \\
\text { - Erabaki lotesleak edo izaera zigortzailekoak eman } \\
\text { - Bere aholkularitza eskatu duenaren ardura hartu. }\end{array}$ & $\begin{array}{l}\text { - Eskuartzearen eta prozeduren inguruan aurkeztu } \\
\text { daitezkeen kexa edo salaketen aurrean informatu edo } \\
\text { txostenak egin. } \\
\text { - Helegite edo ekintza judizialetan partehartu. } \\
\text { - Profesionalen praktika edo erabiltzaileen jarreraren } \\
\text { inguruko iritzi edo epaiak eman. } \\
\text { - Administrazio edo erakundearen beste arlo batzuei } \\
\text { dagozkien gaietan eskuartu (batzorde deontologiko, } \\
\text { diziplinarteko batzorde, sindikatu, etab.). } \\
\text { - Gizarte zerbitzuen arloan, helburu gisa azterketa sozial } \\
\text { edo ekonomikoak dituzten gaien inguruko ikerketa eta } \\
\text { txostenak egitea. }\end{array}$ \\
\hline Osaera & $\begin{array}{l}\text { Batzordeko partaide diren kideak euren ezagutzengatik } \\
\text { izaten dira aukeratuak, eta norberaren izenean } \\
\text { partehartzen dute. } \\
\text { Kide kopuruari dagokionez, ordezkaritza ahalik eta } \\
\text { pluralena izatea komeni da, ikuspegi ezberdinak } \\
\text { izateko, baina aldi berean, talde operatiboak izan behar } \\
\text { dute erabakiak hartu ahal izateko. Horregatik komeni da } \\
\text { diziplina anitzekoa izatea taldea. }\end{array}$ & $\begin{array}{l}\text { Batzordeek diziplinarteko osaera izango dute, lanbide } \\
\text { desberdinen arteko partaidetza orekatua eta gizarte } \\
\text { presentzia kualifikatua bilatuz. Gizarte zerbitzuen } \\
\text { eremuko erabiltzaileekin harreman zuzena eta ohikoa } \\
\text { duten profesionalek eta arreta zuzeneko lanposturik ez } \\
\text { duten pertsonek osatuko dute. } \\
\text { Kide kopuru, partehartze edo prestakuntzari dagokionez, } \\
\text { araudi bakoitzak ezarriko du bete beharreko baldintzak. }\end{array}$ \\
\hline
\end{tabular}

Iturria: Egileak egina.

\subsection{Gatazka etikoak}

\section{2. taulan azaltzen dira gatazka etikoen inguruan batzorde mota bakoitzaren lanerako ildoak.}

\section{2. taula. Batzordeetan lantzen diren gatazka etikoak}

\section{Gizarte eskuartzeko etika batzordeak}

Reamer-ek (1994) 3 egoera edo gaien inguruan ezarri zituen gizarte langileei sortzen zaizkien gatazka edo arazo etikoak eta ikerketa eguneratuagoek erakusten dute (Ballestero, Uriz eta Viscarret, 2011; Vila eta Riberas, 2017) gatazka horiek indarrean jarraitzen dutela. Honela sailkatzen dira:

Batzorde hauek osasun arloan kokatzen direnez, normalean sortu ohi diren gatazka etikoak hurrengo hauek dira:

- Pronostiko txarra duten gaixoen tratamenduekin jarraitu edo ez.

- Hil urreneko gaixoei alta eman edo ez.

- Egoera berezietan tratamenduen izaera proportzionala ezarri.

- Neurri aringarrien hedapena erabaki.

- Ez suspertzeko agindua ezarri.

- Aireztapen mekanikoa eten.

- Noiz eta nola eman gaixoari eta familiari informazioa.

- Noiz eskatu transplanteak egiteko organoak.
1. Erabiltzaileei dagokionez: konfidentzialtasuna, autodeterminazioa, paternalismoa, inplikazio eta distantzia maila egokienak, autoritatearen egikaritza, oinarrizko eskubideak errespetatzea, egiazkotasuna.

2. Erakundeei dagokionez: etika profesionalaren eta erakundearen arauetatik edo goi karguek bidalitako lanetatik sortutako inkoherentziak, baliabide eza edo baliabide desegokiak izatea.

3. Beste profesionalei dagokienez: datuak ezkutatzea edo faltsutzea, intrusismo profesionala, lankidetza eza, konfidentzialtasuna, akordio gabezia, etab.

Aurrez aipatutako ikerketan zehazten da gatazka etiko gehien sortzen dituzten egoerak 3. pertsonei informazioa emate edo ez emateak, erabiltzailearen autonomia errespetatze eta beste profesionalak gaitasunik ez izateagatik salatzeak sortzen dituztela, hurrenez hurren. 


\subsection{Kasuak aztertzeko metodologia}

Ondorengo bi ataletan jasotzen dira bai Etika Asistentzialeko bai Gizarte Eskuartzerako kasuetan batzordeek jarraitzen duten metodologia.

\subsubsection{Etika Asistentzialeko Batzordeak}

Etika Asistentzialeko Batzordeen Gidak, honela deskribatzen du kasuen analisirako jarraitzen den metodologia:

1. Kasuaren egitate kliniko eta psikosozialak aztertu:

a. Gaixoaren diagnostikoa eta arazoak zerrendatzea.

b. Gaixoaren aurreikuspena.

c. Tratamendu aukerak.

d. Kasuaren inguruan erakundeak jarraitzen dituen politikak, praktikak eta araudia.

e. Aurrez antzeko kasuetan egindakoa aztertu.

2. Interesatuen ikuspuntuak identifikatu:

a. Ikuspuntu edo iritziren bat indarkeriaz ezarria izan den zehaztu.

b. Gaixoaren balioak eta lehentasunak zehaztu.

c. Asistentzia taldea antolatu eta gaixoaren egoera aztertu.

3. Galdera eta gatazka edo arazo bioetikoak formulatu.

4. Epe motz, ertain eta luzera eman daitezkeen onurak zehaztu eta balizko arriskuak aztertu.

5. Taldean kontsentsua lortzen ez denean, berau bilatzen saiatu.

6. Ezartze plan bat markatu:

a. Jarraitu beharreko pausoak.

b. Aholkuak, gomendioak edota erabakiak komunikatzeko prozedurak.

c. Aholkuak, gomendioak edota erabakiak (historia klinikoa eta mediku espedientea) dokumentatzeko prozedurak.

7. Planak duen eragina kontrolatu eta behar bada aldaketak egin.

8. Kasuan jarraitu diren prozeduren ebaluaketa:

a. Berrikuspena behar duten prozedura eta politikak zerrendatu.

b. Kasuaren aurkezpena prestakuntza jarraituaren barnean ulertu.

c. Interesatuei berrikuspen prozesua ebaluatu dezatela eskatu.

9. Kasuen errebisio artxibo bat eratu etorkizunean kontsultak egin ahal izateko.

\subsubsection{Gizarte Eskuartzeko Etika Batzordeak}

Kasuen analisirako eredu ezberdinak daude, baina orokorrean, hausnartze edo gogoeta plurala jarraitzen dute erabakiak hartzeko. Reamer-ek (1982) proposatutako ereduak oso ondo laburbiltzen du jarraitzen diren pausoak:

1. Balioen gatazka sortzen duten egoerak identifikatu.

2. Erabaki etikoen eragina jaso dezaketen banakako, talde edota erakundeak identifikatu.

3. Ekintza aukera eta alternatiba guztiak identifikatzen saiatu.

4. Aldeko eta aurkako argudioak aztertu, hurrengo hauetan oinarrituz:

- Izaera orokorreko printzipio eta etika kodeak.

- Gizarte Langintzako Kode Deontologikoa.

- Balio pertsonalak eta balio kulturalak.

5. Sektoreko beste profesional, batzorde etiko eta adituei kontsulta egin.

6. Erabakiak hartu, prozesu guztia erregistroetan gordez.

Hala ere, aipatzekoa da, Eskuartzeko Etika Batzordeak egon arren, eta hauen zereginen artean profesionalak aholkatzea egon arren, gaur egun gatazkak kudeatzeko jarraitzen diren sistema edo modu ezberdinen artean, oraindik konfiantzazko edo lagunak diren profesionaletara jotzen dela gatazka hauek nola kudeatu aztertzeko. 
4.4. Euskal Autonomia Erkidego eta Nafarroako Batzordeen arteko konparazioa

Bi autonomia erkidegoen arteko aldeak deskribatzen dira atal honetan.

3. taula. Gizarte Eskuartzeko Etika Batzordeen azterketa konparatiboa Euskal Autonomia Erkidegoan eta Nafarroan

\begin{tabular}{|c|c|c|c|c|}
\hline & Araba & Gipuzkoa & Bizkaia & Nafarroa \\
\hline Araudia & 14/2011 Foru Dekretua & 46/2007 Foru Dekretua & 232/2006 Foru Dekretua & 6o/2010 Foru Dekretua \\
\hline Jarduera eremua & Probintzia & Probintzia & Probintzia & Autonomikoa \\
\hline Partehartzea & Boluntarioa & Boluntarioa & Boluntarioa & Boluntarioa \\
\hline $\begin{array}{l}\text { Batzordeko } \\
\text { kide kopurua } \\
\text { eta gutxiengo } \\
\text { prestakuntza } \\
\text { bioetikan }\end{array}$ & $\begin{array}{l}\text { Gutxienez } 7 \text { pertsona eta } \\
1 \text { behintzat aditua. } 60 \\
\text { orduko prestakuntza }\end{array}$ & $\begin{array}{l}\text { Gutxienez } 7 \text { pertsona eta } \\
4 \text { behintzat adituak. } 90 \\
\text { orduko prestakuntza }\end{array}$ & $\begin{array}{l}\text { Gutxienez } 7 \text { pertsona eta } \\
4 \text { behintzat adituak. } 120 \\
\text { orduko prestakuntza }\end{array}$ & $\begin{array}{l}\text { Gutxienez } 7 \text { pertsona eta } \\
4 \text { behintzat adituak. } 120 \\
\text { orduko prestakuntza }\end{array}$ \\
\hline Ardura & $\begin{array}{l}\text { Zentro edo erakundeko } \\
\text { gerente edo arduraduna }\end{array}$ & $\begin{array}{l}\text { Zentro edo erakundeko } \\
\text { gerente edo arduraduna }\end{array}$ & $\begin{array}{l}\text { Zentro edo erakundeko } \\
\text { gerente edo arduraduna }\end{array}$ & $\begin{array}{l}\text { Gizarte Zerbitzuen } \\
\text { eskumena duen } \\
\text { departamentua }\end{array}$ \\
\hline $\begin{array}{l}\text { Partehartzearen } \\
\text { iraupena }\end{array}$ & 4 berriztagarriak & 3 berriztagarriak & 3 berriztagarriak & 3 berriztagarriak 9 arte \\
\hline $\begin{array}{l}\text { Urteko gutxieneko } \\
\text { deialdiak }\end{array}$ & 3 & 3 & 3 & 4 \\
\hline Akordioak & $\begin{array}{l}\text { Gehiengo soilez edo } \\
\text { kideen } 2 / 3\end{array}$ & Gehiengo soila & $\begin{array}{l}\text { Gehiengo soilez edo } \\
\text { kideen } 2 / 3\end{array}$ & $\begin{array}{l}\text { Gehiengo soilez edo } \\
\text { kideen } 2 / 3\end{array}$ \\
\hline $\begin{array}{l}\text { Erabiltzaileen } \\
\text { sarrera }\end{array}$ & $\begin{array}{l}\text { Erabiltzaileen arretarako } \\
\text { unitateak }\end{array}$ & $\begin{array}{l}\text { Erabiltzaileen arretarako } \\
\text { unitateak }\end{array}$ & $\begin{array}{l}\text { Erabiltzaileen arretarako } \\
\text { unitateak }\end{array}$ & Batzordeko idazkaritza \\
\hline $\begin{array}{l}\text { Profesional eta } \\
\text { erakundeen sarrera }\end{array}$ & Batzordeko idazkaritza & Batzordeko idazkaritza & Batzordeko idazkaritza & Batzordeko idazkaritza \\
\hline
\end{tabular}

Iturria: Egileak egina. Indarrean dauden legedietan oinarrituta.

4. taula. Etika Asistentzialeko Batzordeen azterketa konparatiboa Euskal Autonomia Erkidegoan eta Nafarroan

\begin{tabular}{|c|c|c|}
\hline & Euskal Autonomia Erkidegoa & Nafarroa \\
\hline Araudia & 153/1995 Dekretua & 435/2001 Agindu Forala \\
\hline Jarduera eremua & $\begin{array}{l}\text { Hurrengo esparruetan kokatu daiteke: a) EAEn } \\
\text { kokatzen den zentro, zerbitzu edo osasun etxea, b) } \\
\text { osasun eskualdea, } \\
\text { c) osasun eskualde bereko edo ezberdineko zentro } \\
\text { bat, baina gehiago ezaugarri edo antzeko arazoak } \\
\text { dituztenean. }\end{array}$ & $\begin{array}{l}\text { Nafarroan kokatutako zentro, zerbitzu edo osasun } \\
\text { etxe bat edo gehiago. }\end{array}$ \\
\hline Partehartzea & Boluntarioa & Boluntarioa \\
\hline $\begin{array}{l}\text { Batzordeko kide } \\
\text { kopurua eta gutxiengo } \\
\text { prestakuntza bioetikan }\end{array}$ & $\begin{array}{l}\text { Gutxienez } 7 \text { pertsona: medikuak, erizaintza } \\
\text { pertsonala, gizartearen ordezkari izango den aditua } \\
\text { eta bioetikan prestakuntza duen pertsona bat. }\end{array}$ & $\begin{array}{l}\text { Gutxienez } 7 \text { pertsona: medikuak, erizaintza } \\
\text { pertsonala, gizartearen ordezkari izango den aditua } \\
\text { eta bioetikan prestakuntza duen pertsona bat. } \\
\text { Osasun arloan edo legegintzan lizentziatua den } \\
\text { pertsona batek parte hartzea aholkatzen da, baita } \\
\text { ikerketa klinikoko eta asistentzia kalitateko etika } \\
\text { batzordeetako kideren batek. }\end{array}$ \\
\hline $\begin{array}{l}\text { Partehartzearen } \\
\text { iraupena }\end{array}$ & 4 urte, berriztagarriak. & 3 urte, berriztagarriak. \\
\hline $\begin{array}{l}\text { Urteko gutxieneko } \\
\text { deialdiak }\end{array}$ & 3. & 3. \\
\hline Akordioak & Gehiengo soilez edo kideen $2 / 3$. & $\begin{array}{l}\text { Orokorrean kideen adostasunez hartuko dira } \\
\text { akordioak. Hau horrela gertatzen ez denean, } \\
\text { txostenetan adieraziko da. }\end{array}$ \\
\hline Erabiltzaileen sarrera & $\begin{array}{l}\text { Gaixoari Arreta emateko edo funtzio hau duen } \\
\text { zerbitzuaren bidez. }\end{array}$ & $\begin{array}{l}\text { Gaixoari Arreta emateko edo funtzio hau duen } \\
\text { zerbitzuaren bidez. }\end{array}$ \\
\hline $\begin{array}{l}\text { Profesional eta } \\
\text { erakundeen sarrera }\end{array}$ & Batzordeko idazkaritzaren bidez. & Batzordeko idazkaritzaren bidez. \\
\hline
\end{tabular}

Iturria: Lloréns eta Morales (2005) eta indarrean dauden araudiekin abiatuta, egileak egina. 


\section{Ondorioak: antzekotasunak eta ezberdintasunak}

Aurreko atalean aztertu diren adierazle eta koadroek, hurrengo ondorioetara eramaten gaituzte:

1. Gizarte Eskuartzeko Etika Batzordeak:

a. Aztertu diren probintzietako Batzordeetan, ez da aurkitzen ezberdintasun adierazgarririk. Aipatzekoa den adierazlea, prestakuntzari dagokiona da, gutxienez eskatzen den prestakuntza 60 ordutik 120 ordura baitoa. Araba da prestakuntza baxuena eskatzen duena eta Bizkaia eta Nafarroa gehien eskatzen dutenak.

2. Etika Asistentzialeko Batzorde eta Gizarte Eskuartzeko Etika Batzordeen artean:

a. Orokorrean eta osotasunean aztertuz gero, bi Batzorde motek antzeko egitura, osaera eta funtzionamendua dutela ikusten da. Biak diziplina anitzeko taldeen bidez osatzen dira, taldean iritzi eta ikuspegi ezberdinak ordezkatuta egon daitezen, hausnarketa eta eztabaida ahalik eta zabalena eta pluralena izan dadin.

b. Batzordeetan lantzen eta aztertzen diren gatazka edo arazo etikoei dagokienez, bi batzorde mota horietan errepikatzen diren gatazkak erabiltzaile eta autodeterminazio printzipioari dagozkio.

c. Batzorde mota hauek betetzen dituzten eta betetzen ez dituzten funtzioen artean ez dago ezberdintasun handirik. Bi kasuetan, bakoitza bere esparrura mugatzen da eta euren funtzio nagusien artean jasotzen diren zalantzen aurrean aholkuak eta iradokizunak ematea dago eta inoiz ez jarduera, erabaki eta jarrerak epaitzea.

d. Kasuen azterketarako erabiltzen den metodo edo metodologia, hausnarketarena da kasu bietan. Hori dela-eta, jarraitzen diren pausoak eta lan modua, nahiko antzekoak dira. Hausnarketaren bidez, planteatzen den gatazkaren inguruko ikuspegi orokor eta oso bat izatea lortzen da Batzordeko kide bakoitzak bere ikuspuntua azaltzeko aukera baitu eta horrela, arazoa ulertzeko modu ezberdinak aztertzeko aukera dago. Iritzi ezberdin hauetatik abiatuta, erabakien inguruko aldeko eta kontrako argudioak aztertzeko aukera sortzen da, ahalik eta erabaki onuragarriena hartzea baliatuz. Hau izan daiteke metodo mota hau erabiltzeko arrazoia.

e. Kasuen azterketen ostean ematen diren aholku eta txostenak inoiz ez dira lotesleak bi batzordeen kasuan, hau da, euren izaera aholku emaile izatea da. f. Gizarte eskuartzeko Etika Batzordeen lan eremua Etika Asistentzialeko Batzordeena baino mugatuagoa da. Lehenak, probintzia mailan kokatzen dira, eta ondorioz, probintzia bakoitzean Batzorde bakarra aurkitzen da sortu daitezkeen gatazka etiko guztiei erantzuteko. Bigarrenak aldiz, probintzia edo autonomia erkidegoen mailaz gain, eskualde edota zentroetan ere aurkitu ditzakegu. Hori dela-eta, batzorde bakoitzak erantzun edo landu behar duen lurralde eremua txikiagoa da, eta honek, sortu daitezkeen gatazka edo arazo etiko gehiago erantzuteko ahalmena izatea ahalbidetzen du edo eremu honetan aurrerapausoak emateko aukera izatea.

g. Batzorde hauetara iritsi ahal izateko kanalak ezartzea oso garrantzitsua da, gatazka etikoak jasotzeko bidea erabiltzaileak eta profesionalak baitira. Hauek aurkezten dituzte kasuak edo euren jardunak sortzen dizkien gatazkak eta dudak eta hauek planteatu ahal izateko mekanismoak eskura izatea beharrezkoa da. Horregatik, bai Gizarte Eskuartzeko Etika Batzordeek bai Etika Asistentzialeko Batzordeek ere, profesional eta erabiltzaileak artatu ahal izateko organo edo unitateak eratu dituzte.

3. Autonomia erkidegoen artean:

a. Aztertu diren bi arloetan, Nafarroan baino lehenago lantzen da legedia EAE mailan, hau da, EAE aitzindari da etika eta batzordeen legegintzan.

b. Kasu honetan ere Batzordeen funtzio, egitura edo iraupenen antzekoa da bi autonomia erkidegoetan.

c. Gizarte Eskuartzeko Etika Batzordeak, Etika Asistentzialeko Batzordeen esperientzian oinarritzen dira euren doitze eta sorreran.

Orokorrean, Etika Asistentzialeko Batzordeak Gizarte Eskuartzeko Etika Batzordeak baino pauso bat aurrerago doaz. Hau horrela izateko arrazoi ezberdinak daude, euren artean aurkitzen direlarik: euren ibilbide, garapen historiko, natur zientziak giza zientziak baino gehiago landu direla, etab.

Hala ere, pixkanaka barneratzen doa eskuartzeek gizartean duten garrantzia eta osasun arloan ematen diren lanketarekin parekatzeko beharra. Horregatik, geroz eta pauso gehiago ematen dira araudi, protokolo edo gida mailan, eta Batzordeek eskaini dezaketen onurak eta aurrerapausoak aitortuz, geroz eta gehiago dira honen beharra ikusten duten profesionalak.

Horregatik, beharrezkoa da bide honetan jarraitzea eta hausnarketa eta eztabaida ildo ezberdinak zabaltzea. 
BALLESTERO, A.; URIZ, M.J.; eta VISCARRET, J.J. (2011):

\section{"Dilemas éticos de las trabajadoras y los \\ "Dilemas éticos de las trabajadoras y los
trabajadores sociales en España", Papers, 97 bol., 4 zb., 875-898 or.}

BIESTEK, F.P. (1957): The Casework Relationship, Londres, Unwin Hyman.

BUTRYM, Z. (1976): The Nature of Social Work, Londres, Macmillan.

CASADO, A. (2016): “Zer da bioetika?”, Euskonews \& Media, 410 zb. [khttp://www.euskonews. com/0410zbk/gaia41001eu.html/].

- (2008): Bioética para legos: una introducción a la ética asistencial, Mexiko, Plaza y Valdés.

EUSKAL AUTONOMIA ERKIDEGOA (1995): “143/1995 Dekretua, otsailaren $7 \mathrm{koa}$, Sorospenerako Etika-Batzordeak sortu eta kreditatzeari buruzkoa", Euskal Herriko Agintaritzaren Aldizkaria, $43 \mathrm{zb}$.

GAZTELA ETA LEONGO JUNTA (2008): Guía para comités de ética asistencial, Gaztela eta Leoneren Osasun Saila.

GOIKOETXEA, M.J. (2013): “El aporte de los Comités de Ética en Intervención Social”, in LEON, F.J.; SIMÓ R.M.; eta V. SCHMIDT, V., Experiencias de los Comités de Ética Asistencial en España y Latinoamérica: análisis de casos ético-clínicos, Santiago, Felaibe, $271-276$ or.

GRACIA, D. (2011): La cuestión del valor, Madrid, Real Academia de Ciencias Morales y Políticas.

IDARETA, F.; ÚRIZ, M.J.; eta VISCARRET, J.J. (2017): “150 años de historia de la ética del Trabajo Social en España: periodización de sus valores éticos", Cuadernos de Trabajo Social, 30 bol., 1 zb., 37-50 or.

NAFARROAKO GOBERNUA (2001): “435/2001 Foru Agindua, abuztuaren 24koa, Osasun kontseilariak emana, Osasun Laguntzako Etika Batzordeak sortu eta kreditatzea arautzen dituena", Nafarroako Aldizkari Ofiziala, 116 zb.
POTTER, V.R. (1970): "Bioethics, the science of survival", Perspectives in Biology and Medicine, $14 \mathrm{zb}$., 127-153 or.

RUBIO, J.M.; eta VARAS, J. (2004): Ámbitos de análisis de la realidad. El análisis de la realidad en la intervención social. Métodos y técnicas de investigación, Madrid, Editorial CCS, 105-124 or.

SACRISTÁN, J.A. (2013): “Patient-centered medicine and patient-oriented-research: Improving health outcomes for individual patients", BMC Medical Informatics and Decision Making, 13 zb., 6 or.

SALCEDO, D. (2000): "La evolución de los principios de trabajo social”, Acciones e Investigaciones Sociales, 11. zb., 79-112 or.

SAN SEBASTIAN, M. (2016): "Palabras similares, diferentes conceptos: Rentas Básicas", Servicios Sociales y Política Social, 110 zb., 73-89 or.

SÁNCHEZ, C. (2008): Situación actual de los Comités de Ética Asistencial en España [Bioetika Masterreko tesina], Kordoba, ICEB [<http://www.bioeticacs. org/iceb/investigacion/tesina.pdf〉].

VIDAL, M. (koord.) (1989): Bioética. Estudios de bioética racional, Madrid, Tecnos.

VILAR, J.; eta RIBERAS, G. (2017): “Tipos de conflicto ético y formas de gestionarlos en la educación social y el trabajo social. Retos en las políticas de formación", Archivos Analíticos de Políticas Educativas, 25. bol., 52. zb. [<https://epaa.asu. edu/ojs/article/view/2651>].

LLORÉNS, L.; eta MORALES, S. (2005): “Bioética y Comités de Ética asistencial en España: comparación de las legislaciones actuales", in TORREGROSA, R.; eta LLORÉNS, L. (koord.), La bioética y la clínica I: una aproximación desde la práctica diaria, saila: Estudios para la Salud, 17. zb., Valentzia, Escuela Valenciana de Estudios de la Salud, 9-36 or. [rhttps://www.scribd. com/document/203970372/La-Boetica-y-laClinica->]. 